\title{
TENSILE TESTING AND DIGITAL IMAGE CORRELATION OF 22MnB5 PRESS HARDENED STEEL (PHS)
}

\author{
A. Rossi ${ }^{a}$, L. Abbade ${ }^{a}$, J. A. C. Lara ${ }^{a, b}$, E. R. B. Jesus ${ }^{\text {c }}$, M. A. Colosio ${ }^{d}$, \\ L. P. Barbosa ${ }^{\text {a }}$, J. L. Rossi ${ }^{\text {a }}$, C. S. Mucsi ${ }^{a}$ \\ a Instituto de Pesquisas Energéticas e Nucleares - IPEN, SP, Brazil \\ ${ }^{b}$ Fundação Santo André - FSA, SP, Brazil \\ ${ }^{c}$ Instituto Federal de São Paulo - Campus Bragança Paulista - IFSP, SP, Brazil \\ ${ }^{d}$ General Motors Mercosul, SP, Brazil \\ * e-mail: andrerossi@usp.br
}

\begin{abstract}
Spot welding is a widely used tool for joining sheets parts in the automotive industry. As $22 \mathrm{MnB} 5$ steel has the adequate mechanical strength to withstand lateral impact and rollover stresses, it was chosen for the use in B-pillar. It was observed the need to study the spot welded joints, due to the increased need of the automobile industry in reducing the weight vehicle and increasing the passengers' safety in compliance with Resolution of the National Traffic Council of Brazil - CONTRAN n ${ }^{\circ} 751$ on the lateral collision test. The microstructure of this steel, in the as fabricated condition, is basically formed by ferrite and perlite, with a tensile strength limit of $600 \mathrm{MPa}$. This steel is designed to undergo rapid cooling during hot stamping. After this process, this steel presents a completely martensitic microstructure and tensile strength close to $1500 \mathrm{MPa}$. This work aimed to investigate the strength of spot welded specimens under different experimental conditions, observing the deformations during the tensile tests. The tests were digitally recorded and the sequenced frames were analyzed using a method called digital image correlation (DIC).
\end{abstract}

Keywords: resistance spot weld, steel 22MnB5, DIC - digital image correlation, PHS, hot stamping.

\section{Resumo}

A soldagem a ponto é uma ferramenta amplamente utilizada para unir peças em chapas na indústria automotiva. Como o aço $22 \mathrm{MnB} 5$ possui resistência mecânica adequada para suportar impactos laterais e tensões de capotamento, foi escolhido para uso no pilar B. Observou-se a necessidade do estudo das juntas soldadas a pontos, devido à crescente necessidade da indústria automobilística em reduzir o peso do veículo e aumentar a segurança dos passageiros em atendimento à Resolução do Conselho Nacional de Trânsito do Brasil - CONTRAN no 751 sobre o teste de colisão lateral. A microestrutura deste aço, na condição como fabricada, é basicamente formada por ferrita e perlita, com limite de resistência à tração de $600 \mathrm{MPa}$. Este aço é projetado para passar por um resfriamento rápido durante a estampagem a quente. Após esse processo, este aço apresenta microestrutura completamente martensítica e resistência à tração próxima a $1500 \mathrm{MPa}$. Este trabalho teve como objetivo investigar a resistência mecânica de corpos de prova soldados a ponto em diferentes condições experimentais, observando as deformações durante os ensaios de tração. Os testes foram gravados digitalmente e os quadros sequenciados foram analisados por um método denominado correlação de imagem digital (CID).

Palavras chaves: solda a ponto, aço $22 \mathrm{MnB} 5$, CID - correlação de imagens digitais, PHS, aço para estampagem a quente. 


\section{INTRODUCTION}

Two important spotlights of the automotive industry are weight reduction and increasing the safety level of passenger cars (BRASIL, 2012) [1]. According to a Resolution of the National Traffic Council of Brazil CONTRAN $n^{\circ} 751$ of 12/20/2018 [2], side crash tests will be mandatory in Brazil after 2020 for all the new vehicles to be legally sold. As a consequence of this legal request, the academic and industry communities are seeking technological solutions for the use of high tensile stress steels ls to be used in structural and reinforcement car body parts.

The $22 \mathrm{MnB} 5$ steel grade is widely used for the press hardening steel process [3-7,10]. In its annealed condition the microstructure is essentially ferritic and perlitic with the ultimate tensile stress of $600 \mathrm{MPa}$. After quenching during the hot stamping process the ultimate tensile stress raises up to 1500 MPa [3-7,11]. The connection of hot stamped parts to the other vehicle parts is widely provided by the spot welding process, due to the high productivity, straightforward execution and suitable quality of the unions.

In this paper, a testing procedure is proposed in order to investigate the behavior of the ductile fracture of spot welded high tensile steels used in in vehicle components. The heat affected zone (HAZ) formed around and after the weld nugget is the weak point of the joining due to the annealing effect of the heating and its later and relatively slow cooling. An automated digital image correlation process [6,12-14] was used to evaluate the recorded images of tensile stress tests in order to measure the local strain of the specimens under testing. The specimens were made out of $22 \mathrm{MnB} 5$ steel both in the annealed and quenched conditions. The quenched condition was chosen to serve as the analogous to the industries press hardened steel as used for the manufacturing of a vehicle B pillar. Figure 1 show where the press hardening steel is placed in a body in white vehicle.
Figure 1. Image of a body in white of a vehicle showing different colors for different classes of steels and the amount in percentage for each class. The PHS steels $(980 \mathrm{MPa}$ to $1260 \mathrm{MPa}$ ) amounts for $3.1 \%$ in mass of the vehicle body in white.
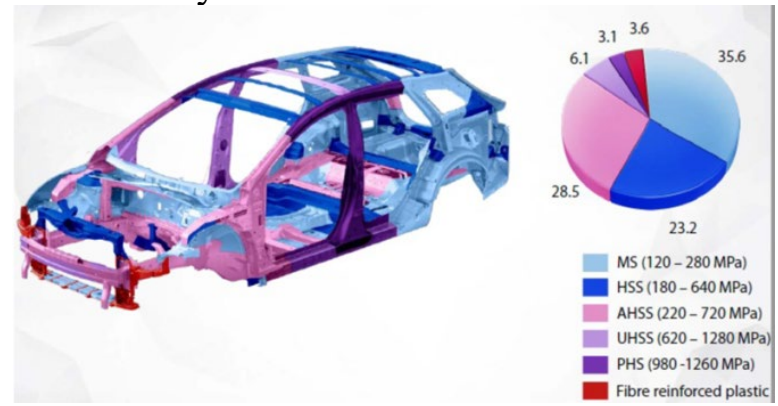

Source: World Auto Steel, 2014.

\section{EXPERIMENTAL}

The following steps were chosen to accomplish the objective of the present work: obtain sheets of $22 \mathrm{MnB} 5$ steel 400 x 500 x $1.3 \mathrm{~mm}^{3}$ from the steel manufacturer; computer aided design - CAD project of the tensile test specimens, the backing plates and the welding jig; laser cut all the sheet steel parts; manufacture the welding jig; water quench half the total quantity of specimens and backing plates; flat grind the excess material on the side of the samples to meet specifications; spot weld the back plates to the specimens following the chosen weld parameters; specimens surface preparation and stochastic application of paint dot patterns; record the tensile tests specimens surface with digital cameras; process the video films and export the files to the freeware DIC software; automatically evaluate the quality of the dot pattern regarding the information entropy; analyze the data sets and the engineering strain-stress curves generated by the universal tensile test machine.

\subsection{B Pillar}

In Figure 2, it is shown a typical vehicle B pillar produced using the PHS process and the location where similar tensile test specimen could be machined out of quenched 22MnB5 
steel emulating the heat treatment during the press hardening forming process. In the present work it was used heat treated specimens instead of press hardened specimens.

Figure 2. a) shows a vehicle B pillar produced using the PHS process. Figure 2 b), The location where a similar tensile test specimen machined out of quenched 22MnB5 steel emulating the PHS process.

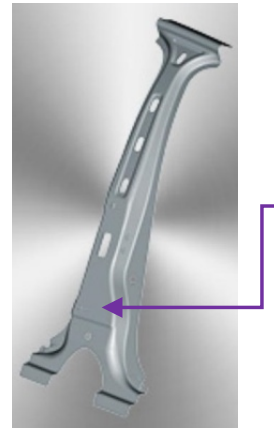

a)

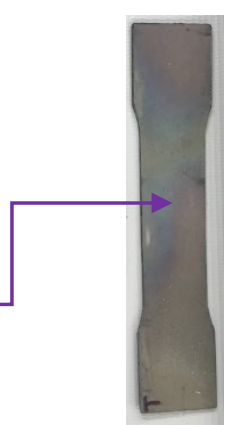

b)
Source: a) kirchhoff-automotive.com. Source: b) author.

\subsection{Welding jig}

A welding jig was developed in order to keep the welds centerline symmetric and keep the specimens under strict dimensional control. The jig was totally built at the IPEN's machining workshops. Al the parts of the jig were built in a fiber reinforced phenolic resin composite, a material resistant to relative high temperatures and it is an excellent electric insulating material. Figure 3 shows the assembled parts of the jig, a base, an Lshaped edge and a centering plate for the spot weld electrode.

Figure 3: Image of the welding jig machined out of a Celeron plate, showing the three main parts, the base, an $\mathrm{L}$ shape support and the centering plate.

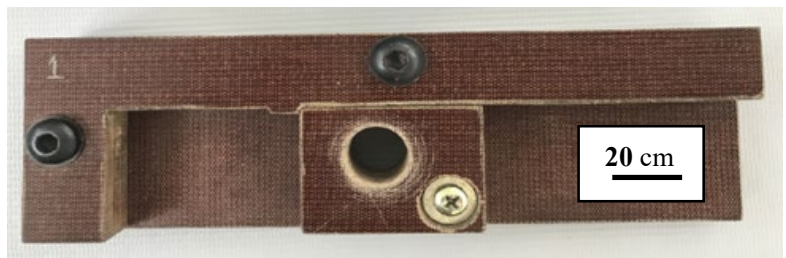

Source: author.

\subsection{Non standardized tensile test specimens}

Experimental specimens were prepared out of standard specifications to check the viability of the assembly; welding and testing for the tensile stress tests were made out of 22MnB5 sheet steel with the following dimensions: 30 x $145 \times 1.3 \mathrm{~mm}^{3}$ without the gage length reduction. Initially the bulk steel sheets were shear cut to slightly oversized dimensions. Same quantity of the so called backing plates were cut with the dimensions: $30 \times 40 \times 1.3$ $\mathrm{mm}^{3}$. Figure 3 shows the evolution of the assembly of the tensile specimen. Figure 3 a) shows the back plate to be spot welded to the longer plate. Figure $3 \mathrm{~b}$ ) shows the image of the welded specimen and the backing plate. In figure $3 \mathrm{c}$ ) the backing plate and main sheet are welded together after quenching. Figure 3 d) shows the face of the main plate opposite to the backing plate just before this surface been painted with the dot pattern.

Figure 3. a) Image of the backing plate. b) Image of the welded specimen and the backing plate. c) Opposite side of the specimen showing the spot weld nugget. d) Image of the specimen after dot pattern painting.

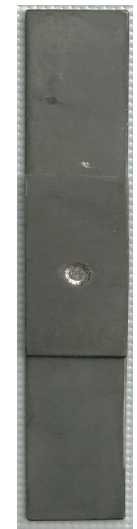

b)

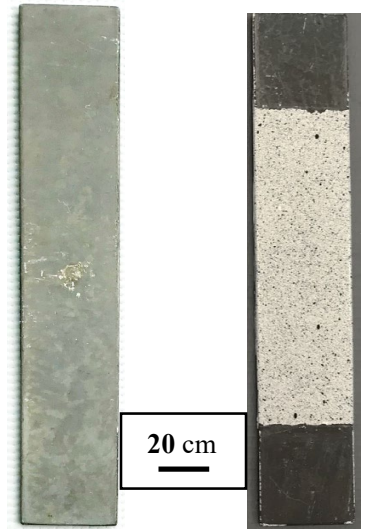

c)

d)

Source: author.

\subsection{Standardized tensile stress test specimens}

Following the initial experiments depicted in 
the previous section, a set of specimens were prepared using the $1.3 \mathrm{~mm}$ thickness $22 \mathrm{MnB} 5$ steel plates either in the condition as provided by the manufacturer and other in water quenched condition. The shape of the specimens is according to the JIS Z 2241 (Japanese Industrial Standard). The quenching process used in the present work was chosen to simulate the industry's press hardening steel process. In the PHS process a plate of steel is heated to a temperature above the austenitizing temperature and then pressed to the shape of the desired part in a water cooled die set $[3-7,11]$.

For the 22MnB5 steel used in the present work, the material was heated to $950{ }^{\circ} \mathrm{C}$ for 5 minutes and then quenched in water [15]. In the experiments, half of the total quantity of specimens (backing plate and specimens) were quenched while the other half was kept in the as received conditions, i.e., without heat treatment.

Figure 4 shows the drawing and the dimensions of the specimens according to the JIS Z 2241. The material was laser cut oversized and then the sides were grinded in a flat grinder to keep the side surface as smooth as possible, diminishing the possible effects of stress concentration in the roughness favoring the beginning of side cracks.

Figure 5 shows the image of the laser-cut and tempered specimen and a backing plate for spot welding according to JIS Z 2241 standard specimen and the image of the lasercut and tempered specimen and a backing plate after spot welding as it will be described as follows.

Figure 4. Tensile test specimen's dimensions in $\mathrm{mm}$, according to JIS Z 2241 [8].

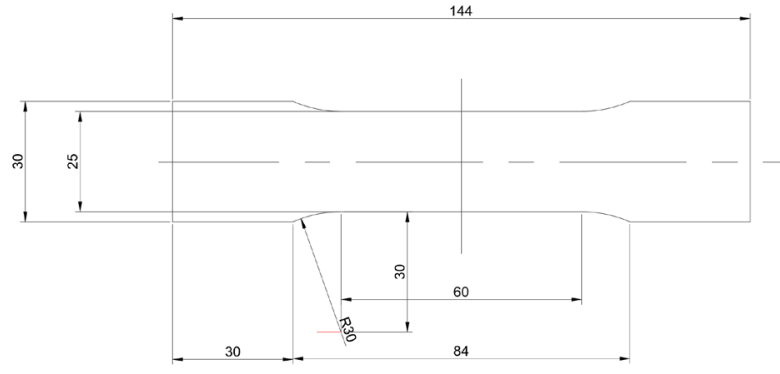

Source: author.
Figure 5. a) Image of the laser-cut and tempered specimen and a backing plate for spot welding according to JIS Z 2241 standard specimen. B) Image of the laser-cut and tempered specimen and a backing plate after spot welding.

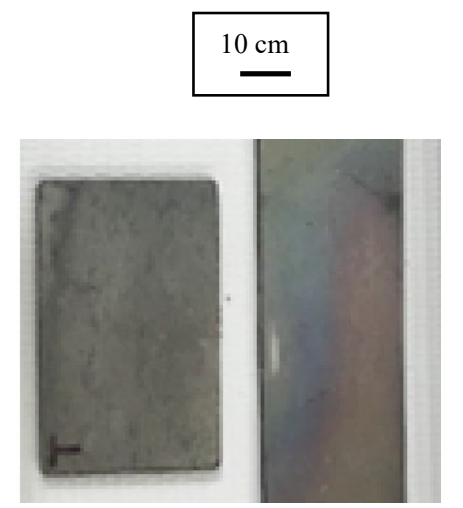

a)

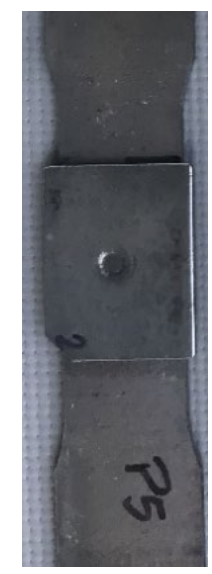

b)
Source: author

\subsection{The spot welding parameters}

The electric spot welds were done at the laboratories of Santo André Foundation (FSA). The spot welding machine with electrodes $6 \mathrm{~mm}$ diameter, see Figure 6 which shows the machine, power control panel, force panel and a cooling system for the electrodes. A computer connected to the weld machine to control the welding parameters.

\subsection{The digital image correlation software}

The software for the digital image correlation analysis in this paper is a freeware version of the professional version of the GOM Correlate software. The freeware version is limited to two-dimensional analyses. Basically the software distributes facets systematically throughout the image of the surface of the specimen. Each facet is a square identified by a set of stochastic dots. Since the dots are locally stochastic then each facet is a facet totally uncorrelated to other facets. This principle sets on the basis of the software. The second principle is the digital image correlation itself with a desired property such as the strain. The facets are painted on the specimen surface and distort 
concomitantly in conjunction to the specimen under test. The software performs a twodimensional correlation operation between two different moments of the faces images; this correlation operation provides the strain in the two linearly independent directions $\mathrm{X}$ and $\mathrm{Y}$ for a given elapsed time. The operation is automated to allow the evaluation of the strains for each facet of the specimen throughout its surface for each instant of time. After this being undertaken a twodimensional interpolation of the results allow the generation of both a color map of strains and the curves of local strains, chosen by the user.

Figure 6. a) Image of the used spot welding machine located at Santo André Foundation (FSA). b) Image of the computer screen where the parameters for welding are entered.

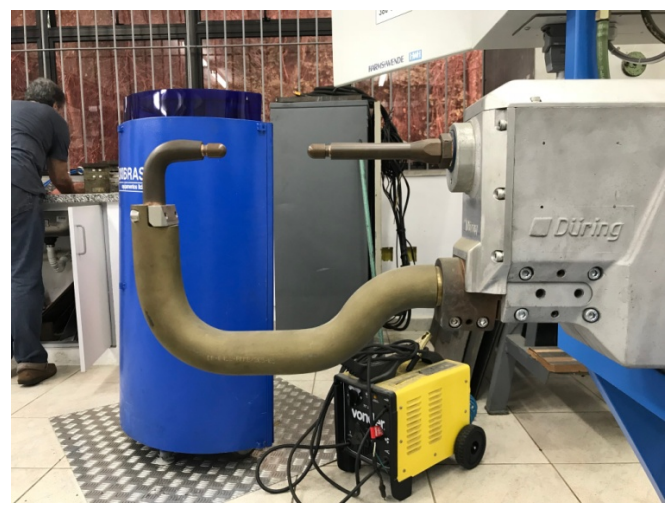

a)

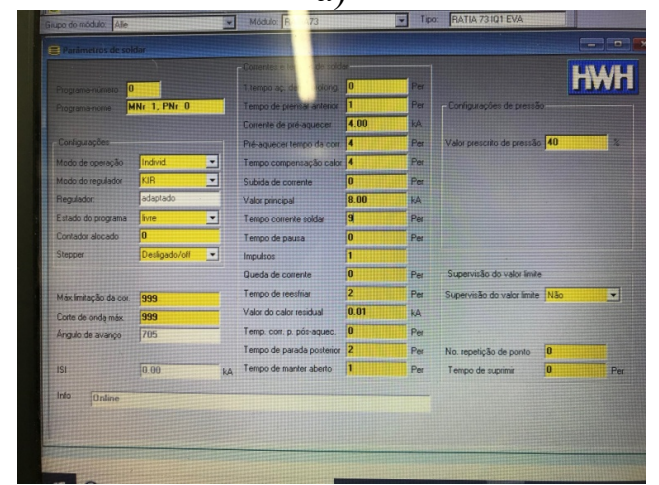

b)

Source: author.

\subsection{Painting the stochastic pattern of dots on the specimen surface}

The stochastic pattern of dots is necessary for the software to recognize the facets on the surface of the specimen. The manufacturer recommends a base layer of white paint thoroughly applied to the surface followed by a spray of coarse droplets of black paint in order to obtain a high contrasting image of black dots on a white surface. For the DIC evaluation of the specimens strains two different patterns were applied one fine, see Figure 7 a) and the other coarse as shown in Figure $7 \mathrm{~b}$ ).

Figure 7. a) Image of the specimen with making finer and more discrete points. b) Image of the specimen with making thicker and more evident dots.

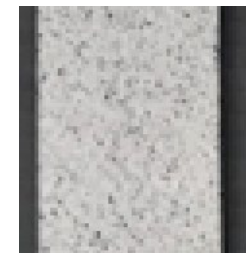

a)

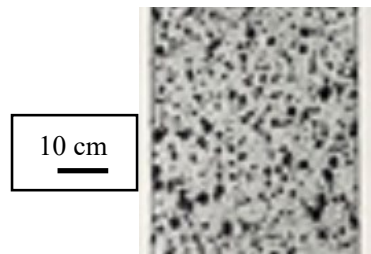

b)
Source: author.

\subsection{Tentative methods for the painting of the stochastic pattern of dots on the specimen surface}

Two alternatives for the painting of the stochastic pattern of dots on the specimen surface were attempted. For quenched specimens with a dark surface, white dots were painted right on the specimen surface after a thorough cleaning with an organic solvent, as shown in Figure 8 a). The other tentative was sanding out the dark scales from the specimens surface, thorough cleaning and then applying black paint dots right on the specimens surface, as shown in Figure 8 b).

Figure 8 . a) Specimen's image with generation of white dots directly on the specimen surface. b) Image of the specimen with generation of black dots directly on the surface of the sanded specimen.

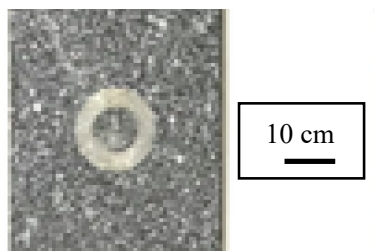

a)

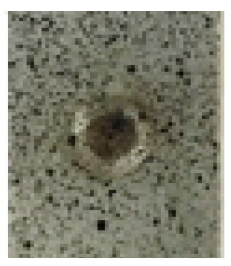

b)
Source: author. 


\section{RESULTS AND DISCUSSION}

Vtech, the representative office in Brazil, provided the freeware version of the GOM Correlate software. The basic working of the software as described earlier in this paper analyzes the initial image and makes comparisons with the images generated during the deformation of the specimen during the tensile test. The software allows the evaluation of image or video series files, with a range of evaluation and report generation possibilities. The version of the chosen software was obtained free of charge. Figure 9 illustrates the evolution of the digital image correlation process. Detail a), the specimen without heat treatment welded in its initial state. Detail b), the same specimen after a deformation, with a rectangular region chosen manually for analysis and detail c), being the same region chosen previously, with the image correlation of the deformations.

Figura 9. Evolution images generated in the digital image correlation process. a) The dot painted surface of a specimen. b) The overlaid image of the strain field, in the long axis of the figure. c) Is the strain field at an instant of the tensile test just before the specimen rupture moment.

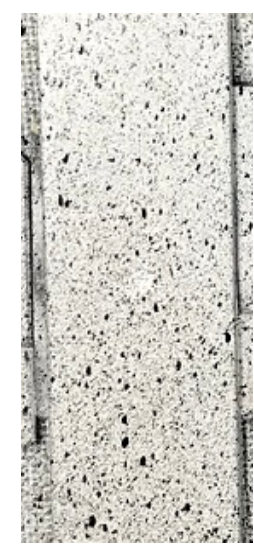

a)

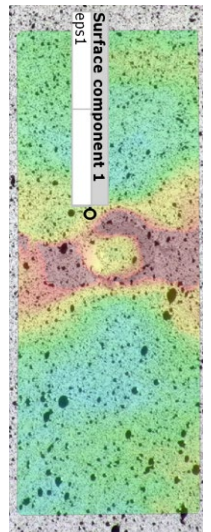

b)

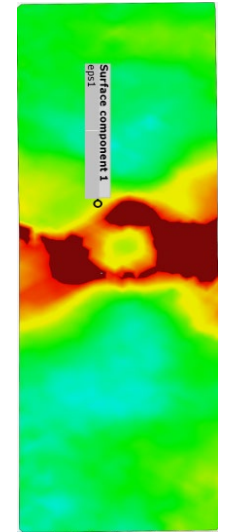

c)
Source: author.

The color scale maps colors and strains allowing the visual observation and recording of the strains on the specimen surface. The red color represents the largest deformations and the blue the smallest. The other colors represent the intermediate ones [6]. Figure 10 illustrates the image of the GOM screen with the image of the specimen. Another software output is shown in Figure 10. A set of curves is traced for the evolution of the strain for a set of points choose on the specimen surface; the points are denote on the color map locate at the right side of the Figure 10.

Figura 10. a) GOM software screen showing the image of the specimens. b) Partial image of the GOM screen showing a set of curves is traced for the evolution of the strain for a set of points choose on the specimen surface; the points are denote on the color map locate at the right side of the figure.

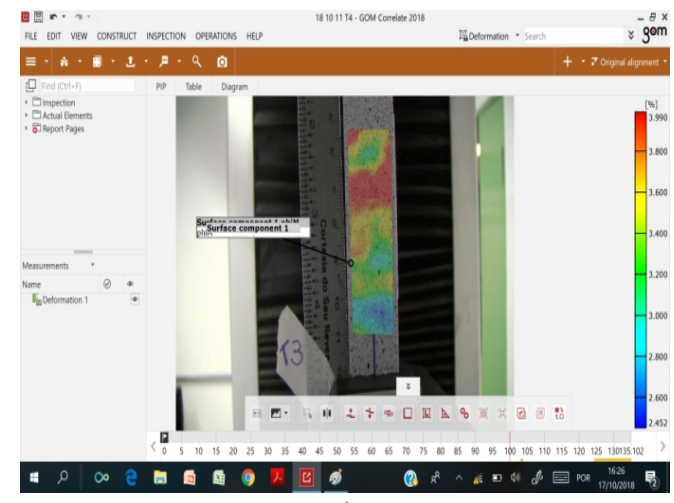

a)

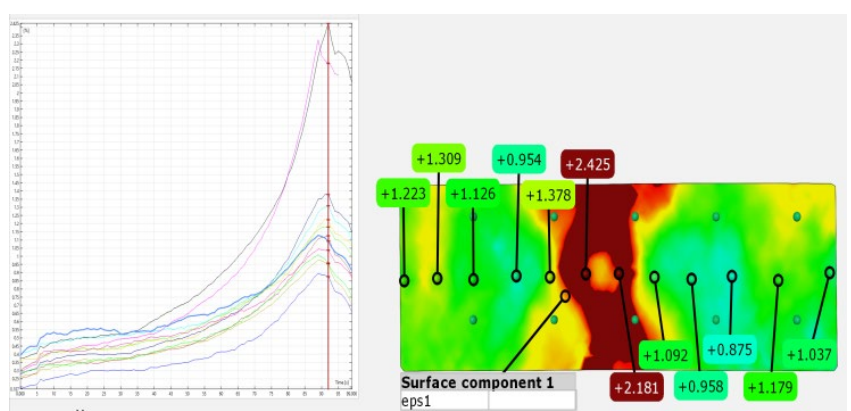

b)

Source: author.

Concerning the painting routes tested for the painting of the stochastic dots, all performed well but with characteristic concerns. The surface preparation as suggested by the software developer provides a high contrast between the lack dots on the white surface providing better color maps in the output results. The method shows a deficiency when the specimen is close to rupture and the white base paint detaches from the steel surface. It was observed that small dots yield better results than the coarser ones. 
The alternative methods of surface preparation were characterized by low contrast between the surface and the dots, either white or black, requiring careful work o lighting. The shine of the metallic surface cause distortions on the digital filming. The first method proved a yield of better results for the experiments but the authors do not exclude the other test methods using better lighting conditions, material surfaces or lens filters.

Figure 11 a) shows one of the specimens of unquenched material, parts of the spot welded back plate can be seen in the image, in which the rupture happened far from the spot welded region. The test was carried out using a rate of displacement of $2.5 \mathrm{~mm} \cdot \mathrm{min}^{-1}$. It is suggested that the crack happened far from the spot welded region because the steel may be slightly quenched at the weld. Then the cross section of the weld may have a higher mechanical resistance at the weld than the rest of the specimen. Figure $11 \mathrm{~b}$ ) an assembled specimen of quenched material after being broken during a tensile test, again the back plate can be observed behind the main plate. The test was carried out using a rate of displacement of $2.5 \mathrm{~mm} \cdot \mathrm{min}^{-1}$. The crack surrounds the weld spot and follows diagonally to the edges of the main plate, nothing happens to the back plat, as expected. The strains just before the rupture of the sample can be seen on Figure 10. The quenched material of the main sheet should exhibit a higher ultimate stress then the heat affected zone (HAZ) formed around the spot weld with possibly an annealed structure.

Figure11. a) Image of the specimen, without quenching, breaking outside the weld region. b) Image of the tempered specimen, with break around the ZTA.

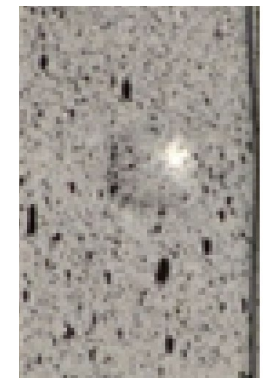

a)

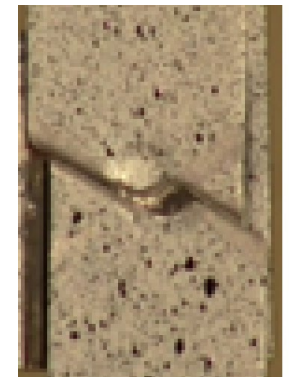

b)
Source: author.

\section{CONCLUSION}

The color mapping of the strain distributions on the tensile test specimens during the tests allows the observation of the most favorable region for the crack formation and rupture of the sample. This may allow the comprehension of the importance of the dimensioning of parts, regarding the formation of a heat affected zone around the spot weld nugget [9]. This may be caused by the annealing that may occurs at the heat affected zone, since the heat generated at the weld can only flows through the plate, heating it and lowering the quantity of the original martensite of the material, inducing the formation of ferrite otherwise.

It was observed that every technique use to the painting of stochastic distributed dots through the samples in this study respond well to the GOM correlate software. The drawbacks found are characteristic to each case. The traditional white base layer with black dotes proved versatile, but strongly depends on the adhesion of the base paint layer on the tensile specimen. The other methods overtake this problem but problems regarding lighting and contrast were not already solved as well as the possible use of light filters. This investigation does not conclude about the samples surface preparation and strongly suggests that the methods must be adapted to each case of study.

\section{ACKNOWLEDGMENTS}

The authors wish to acknowledge to IPEN, IFSP, FSA, CAPES, ArcelorMittal, Düring and Vtech.

\section{REFERENCES}

[1] BRAZIL, Brasília. Law $N^{o} 12.715$, of 17 Sept. 2012. Art. 40 institutes the Program to encourage technological innovation and densification of the automotive vehicle production chain - Inovar - Auto, 2012. Available in:

$<$ http://www.planalto.gov.br/CCIVIL_03/_At o2011-2014/2012/Lei/L12715.htm>.

Accessed 20 Dec 2018. (In Portuguese) 
[2] CONTRAN n ${ }^{\circ}$ 751. Resolution of the National Traffic Council of 12/20/18. Side impacts for vehicles. Available in $<\underline{\text { http://www.in.gov.br/materia/- }}$ /asset publisher/Kujrw0TZC2Mb/content/id/ 57495685.

http://www.normasbrasil.com.br/norma/resolu cao-751-2018 373328.html $>$. Accessed 15 Jan 2019. (In Portuguese)

[3] KARBASIAN, H.; TEKKAYA, E. A. A review on hot stamping. Journal of Materials Processing Technology, v. 210, p. 2103-2118, 2010.

[4] ARCELORMITTAL USIBOR $®$-AS patent case to be reviewed in district court. Available in: $<$ http://corporate.arcelormittal.com/newsand-media/news/2013/april/22-04-2013>. Accessed 10 Sept 2018.

[5] CANTOR, B.; GRANT, P.; JOHNSTON, C. Automotive engineering - lightweight, functional and novel materials: Future vehicles and materials technologies. United Kingdom. Published by CRC press, $1^{\text {st }}$ Edition. February 19, 2008. $296 \mathrm{p}$.

[6] VTECH CONSULTING LTDA. GOM Testing. Technical Documentation as of V8 SR1. Digital Image Correlation and Strain Computations Basics. 000000118_004_EN_1611-2016. Braunscheig, Germany, 2016.

[7] GORNI, A. New trends for the hot stamping process. 2011. Available in:

$<$ http://www.gorni.eng.br/Gorni_CongCCM_20 11.pdf $>$. Accessed 15 Oct. 2018. (In Portuguese)

[8] JIS Z 2241 Metallic Materials - Tensile Testing - Method of Test at Room Temperature. $11^{\text {th }}$ Edition, October 20, 2020.
[9] SATO, K.; FUTASUKA, T.; HIRAMOTO, J.; NAGASAKA, K. Ductile fracture from spot weld and flange edge in advanced high strength steels. SAE Int. J. Engines 10(2):2017.doi:10.4271/2017-010365 .

[10] MATERIAL SERIES. High Performance Steel Forming and Application Seminar (CA ${ }^{3} \mathrm{D}$ 2018). IPT - Technological Research Institute of the State of São Paulo, SP, Brazil, 2018.

[11] DEVA, A.; JHA, N. K.; JHA, B. K. Effect of austenitising temperature and cooling condition on mechanical properties of low carbon boron containing steel. International journal of metallurgical engineering, v. 1, p. 1-6, 2012.

[12] NUNES, L. C. S; CASTELLO, D. A.; MATT, C. F ; SANTOS, P. A. M. Parameter estimation using digital image correlation and inverse problems. Solid Mechanics in Brazil, vol.1, pp 433-443, 2007.

[13] BARRETO Jr., E. Use of the correlation method in the characterization of metallic and polymeric materials. Masters dissertation, Federal Fluminense University, Rio de Janeiro, Brazil, 2008. (In Portuguese)

[14] BERFIELD, T.A.; PATEL, J. K.; SHIMMIN, R. G.; BRAUN, P. V.; LAMBROS, J.; SOTTOS, N. R. Micro-and nanoscale deformation measurement of surface and internal planes via digital image correlation, Experimental Mechanics, v. 47, pp.51-62, 2007.

[15] RAMALHO, R.; LISBOA, C.; COSTA, L. L.; SCHAEFFER, L. Microstructure and microhardness analysis of 22MnB5 hot stamped steel. $37^{\text {th }}$ SENAFOR, Porto Alegre, Brazil, 2017. 